\title{
OBESITY AMONG PRIMARY SCHOOL CHILDREN IN PORT SAID GOVERNORATE ; PREVALENCE AND ASSOCIATED FACTORS
}

\section{Prof. Gehad Mohammed Abo-Elmaty; Prof. Mohamed Mohamed El-Mazahy ; Dr ,Naglaa Ibrahim Mohamed Gida; Salwa Saleh Abdel-Fattah}

Professor of Family \& Community Health Nursing, Faculty of Nursing, Port Said University; Professor of Pediatrics Medicine Faculty of Medicine Al-Azhar University ; Assistant Professor of Family \& Community Health Nursing- Faculty of Nursing Port Said University; Lecturer of Family \& Community Health Nursing, Faculty of Nursing, Port Said University; Lecturer of Pediatrics Medicine Faculty of Medicine Al-Azhar University ; B.Sc. Nursing - Faculty of Nursing - Port Said University.

\section{ABSTRACT}

Background: The prevalence of primary school children obesity is rising at an alarming rate world wide children obesity have been observed in developed countries, however, its prevalence is increasing in developing countries as well. Aim this study aimed To assess the obesity among primary school children through prevalence and associated factors. Subjects and method: Design : A descriptive cross-section research design the study. Setting : This study was carried out in five governmental primary schools in Port Said city region. subjects : A Cluster Sample was selected randomly it compromised of 697 students. Tool : Two tools were utilized to collect necessary data in this study. Tool one Interviewing questionnaire sheet was used to collect data about socio demographic character and life styles of children. Tool two body mass index. Results : The overall prevalence of overweight and obesity was 20.6\%. revealed that the most independent significant predictors of overweight/obesity are, income enough $45.3 \%$ more than three quarter were eating during TV watch or computer use, $33.3 \%$ were fast food ,50.7 \% eating before bed and $68.8 \%$ were no eating vegetables regularly, In addition, $41 \%$ no eating breakfast. Conclusion: This are a high significant relation between normal weight and over weight and obesity with eating habit and also eating out side the home and taking snakes. Recommendations: Educational efforts and reinforcement must be continuous to meet the needs of the parent and their children among primary schools

Keywords: Associated factors, Obesity, Prevalence, Primary school children 


\section{INTRODUCTION}

Obesity can be defined as a condition of abnormal or excess fat accumulation in adipose tissue, to the extent that health may be impaired (EI-shafie, Hogran and Dohein 2014). Obesity is the result of caloric imbalance (too few calories expended for the amount of calories consumed) (Sanjay, 2016). Body mass index (BMI), a number that conveys the weight for height relationship as a ratio (weight in kilograms divided by the square of height in meters), is the standard measure for assessing obesity in children and adolescents (center for disease control and prevention 2009)

The prevalence of children in primary schools of obesity is increasing in all countries, with the most rapid rise in low- and middle income countries the majority of overweight or obese children live in developing countries, where the rate of increase has been more than $30 \%$ higher than that of developed countries. Children obesity has more than tripled in the past 30 years. The prevalence of obesity among children aged 6 to 11 years increased from 6.5\% in 1980 to 19.6\% in 2009 (Pangani, Kiplamai and Kamau, Onywera, 2016). According to center for disease control and prevention data for 2014, $17.9 \%$ of children aged 6-11 are overweight. (norman, Trmple and ted Wilson, Geroge, Bray 2014).

Multiple factors influence weight, including genetic factors, endocrine levels, activity levels, metabolic rates eating patterns and stress, behavioral, lifestyle, and environmental factors Although a positive balance between energy expenditure and energy intake is a possible underlying cause of obesity. (Abd EI-matty, 2009). sedentary life style, over eating, fast food diet, lack of adequate nutritional education, school environment and advertising and marketing of unhealthy foods (Kuhle, Doucette, Vallis HP and Sara, Kirk, 2015)

There are many complications of the obesity such as metabolic syndrome and respiratory complication (sleep apnea syndrome, asthma, hypoventilation), CHD (Dyslipidemia, hypertension, inflammation, hypercoagulability), cancers (colorectal, Esophageal, Endometrial, Breast (postmenopausal), kidney, gastrointestinal complication cholecystitis, nonalcoholic fatty liver), endocrine (type 2 diabetes mellitus) as well as Gout, Kidney stones, osteoarthritis, fertility and pregnancy complications psychological, and social problems Increased morbidity and mortality throughout life (James and Rippe 2012). 
Therapeutic strategies of children obesity include psychological, family therapy interventions, lifestyle or behavior modification and nutrition education. The methods used in the obesity treatment are gathered under 5 group 1. Medical nutrition (Diet) Treatment, 2. Exercise Treatment, 3. Behavioral change treatment 4. Medicine treatment5. Surgical treatment Obesity treatment should be performed with a team consisting from a doctor, dietician, psychologist and physiotherapist (Ankara 2010).

The health care system including community health nurse plays an important role in both prevention and treatment of obesity.Community nurses can provide essential leadership in helping students maintain a healthy weight to prevent overweight and obesity, decrease the burden of illness, and increase the quality of life. Preventing and treating overweight. A school nurse can influence a child and his/her family to make healthy lifestyle changes by. Identifying students who may need further evaluation by conducting screenings (height, weight and body mass index [BMI]) and assessing students for possible risk factors associated with overweight and obesity making possible early referrals to health care providers for further assessment and treatment (National association of school nurses, 2013).

\section{Significance of the study}

In Egypt, the prevalence of overweight and obesity among school age children in 2013 was 17.7 and 13.5\%, respectively. (EL-Gilany, 2011 and Ameen and Abdelazeim, 2015) stated that obesity is a public health priority because it is associated with a diverse range of morbidities and it may interfere with normal psychosocial, emotional, and physical development.

There are more and more researches in Egypt focused on obesity in different ages but there is very little are known focused on obesity among primary school children, so the aim of this study will be to assess the prevalence and risk factors obesity among primary school children at Port Said.

\section{AIM OF STUDY :}

This study aimed to assess the obesity among primary school children through prevalence and associated factors. 


\section{SUBJECTS AND METHOD:}

\section{Research design}

A descriptive cross-section research design was utilized to in this study.

\section{Study setting:}

This study was carried out in governmental primary schools in Port- Said city region in Port Said city five schools randomly selected them. One school from each educational region these include: North Port Said (Tariq Ibn ziyad), South Port Said (Atef- Sadat) , East port said (Om EL moamenin), Port fouad (Sinai primary) and Bahr AL Baqar (EL Sabbaheia)

\section{Study subjects:}

The subjects of the study compromised of 697 children from the primary schools. The total number of primary school children of the public school in Port Said is 2893 students.

\section{Sample size:}

Sample size calculation

The sample size was calculated using Medcalc program. The total number of primary school children of the public school in Port Said is 74125 students. At least $19.6 \%$ of children are obese (El-Shafeiet al., 2014), with the alpha error of 5\%, study power of $80 \%$, a precision of $3 \%$ and a design effect of 1.5 due to cluster sampling method, and then the sample size will be 633. A $20 \%$ will be added to compensate for defaulters thus the final sample size is 697 at least (Centers for Disease Control and prevention 2011).

\section{Tools of data collection:-}

\section{Tools for Data collection: two tools was used in this study}

The data was collected through utilizing the following two tools:-

Tool I: Structured Interviewing questionnaire. It was designed and utilized by the researcher to collect the necessary data. It was divided into two parts entitled the following items: 
The first part: It includes questions related to socio demographic data characteristics as (fathers Education and occupation, mother education and occupation, family size, monthly income .....etc.).

The second part: It includes questions relating to children life style pattern such as eating between meals, taking dinner, eating while watching TV, eating outside the home, computer use daily,duration of sleep, watching TV, playing sport,sleeping after meals. Practicing physical exercise, Walking to school.

Tool II: Body mass index (BMI). BMI is calculated by dividing the weight in kilograms by the square of height in meters [BMI $=$ weight $(\mathrm{kg}) /$ height $\left.\left(\mathrm{m}^{2}\right)\right]$. According to the BMI, obesity is defined as a body mass index of $30 \mathrm{~kg} / \mathrm{m}^{2}$ or higher, whereas individuals whose BMI is between 25 and $29.9 \mathrm{~kg} / \mathrm{m}^{2}$ are termed overweight or pre obese. (Abd EI-matty, 2009)

\section{Scoring System for tool one:}

For the children life style about score of $50 \%$ or more was considered as satisfactory, scores less than $50 \%$ will be considered as unsatisfactory.

\section{Validity}

The tool was ascertained by a jury composed of seven experts in nursing field. Their opinions were elicited regarding the tool layout

\section{Reliability}

Cronbach's alpha coefficient was calculated to assess the reliability of tool I the developed tools through their internal consistency ,alpha $=0.77$

\section{Pilot Study:}

The pilot study was carried out on $10 \%$ of the total students in Port Said public primary schools (there were 70 students the researcher was selected $10 \%$ from each schools, which were equally selected of the 3-4 student class from the first, second, third, four, five, six years. It conducted over a period of one month from the beginning of October 2016 to beginning of November 2016.the sample of the students included in the pilot study were excluded from the main study sample. 


\section{Field work}

Before beginning collection of the data, an agreement of educational management's director at Port Said City obtained ,this step take one month at February 2017.The purpose of the study was explained to each children agreed to participate in the study prior to their homes to be filled by one of their parents or guardians, an oral consent was obtained from them. The researcher knew and determined the suitable time to the students by the deans of each schools according to their class schedule. After having got the agreement consent, the researcher measured the height, and weight for each student in the examination room of the school. The researcher himself did all measurements and the registration; and then the students were asked to take the questionnaire to their homes to be filled by one of their parents or guardians asked them to bring it on the following day. By the researcher collected on the next day. The study was conducted from the beginning of February 2017 till the end of July 2018. Data was collected through about three days a week. The researcher were attending 36 days in three months, The number of schools was very large number of student there were three schools to take 8 days in each school and the other two schools having small number of student take six days at each school to obtain the required questionnaire. The present study consumed about 18 months, 10 month of them for obtaining the official permission, pilot study and modifications of the tool. The next three months consumed for data collection and the last five months consumed of data entry and statistical analysis.

\section{ADMINISTRATIVE DESIGN:}

Before conduction of the study, an official letter explaining the aim of the study was issued from the Dean Faculty of Nursing, Port Said University to the director of educational management at Port Said City to obtain his permission to conduct the study an agreement was taken from director of each schools, after explanation of the purpose of the study.

\section{Ethical Considerations:}

An explanation of this study to the director of education managements in Port Said was done to take their permission to carry out the study. Agreements of children and parents was done before participation in the study. The participants was informed of 
the purpose of the study. Participants was assured about the confidentiality by write in the above questioner of the information gathered that was used for the purpose of the study.

\section{RESULTS:}

Figure (1): Distribution of the studied school children according their level of BMI. The prevalence of overweight is $14.9 \%$ and obesity is $5.7 \%$ while underweight $37.0 \%$ and normal weight $42.3 \%$.

Tables (1): shows that relationship between characteristics of the studied school children and their BMI. These was a significant differences between normal weight BMI in different School region groups, child age, class groups and residence were Pvalue $<\mathrm{P} 0.011, \mathrm{P}<0.000, \mathrm{P}<0.003 \mathrm{P}<0.035$ respectively.

Although male school children showed increase in average BMI than females but the differences is not significant $\mathrm{P}$ - value $<0$. 928. These is no significant difference in normal weight BMI of studied school children as sibling number, respectively $\mathrm{P}$ value $>0.05$.

Tables (2): shows that Comparison between school children with normal weight and overweight and obese group as regard their behaviors. these was a significant differences between normal BMI in different child sit on front of TV /computer groups and number of hours child sit on front of television /computer were $\mathrm{P}$ - value $<0.033, \mathrm{p}$ - value $<0.019$ respectively. The table reveal that there was a significant differences between average BMI in different Sleeping hours per day groups beside higher in sleeping 8 hours per day $59.7 \%$.

Tables (3): shows that Comparison between school children with normal weight and overweight and obese group as regard their eating habit. these was a significant differences between BMI in different Number of eating per day, eating during TV watch or computer use, number of meals, eating breakfast, eating before going to bed, fast food, number of eating sweets, favorite food to your child, eating vegetables regularly and eating food at school P - value $<$ P 0.022, P 0.032, P 0.000, P 0.036, P 0.034, P 0.021, P 0.030, P 0.042, P 0.012and P 0.037 respectively. 
Tables (4): shows that Comparison between school children with normal weight and overweight and obese group as regard their Eating outside home and taking snacks. these was a significant differences between normal in different overweight and obese group as regard eating at restaurants, number eating in the last week, eating snacks, types of snacks were $\mathrm{P}$ - value $\mathrm{P}<0.035, \mathrm{P} 0.010, \mathrm{P} 0.018, \mathrm{P} 0.001$ respectively.

Tables (5): shows that comparison between school children with normal weight and overweight and obese group as regard their eating salted food and types of juices. These was a significant differences between normal BMI and the child eating salted food and types of juices child drink beside higher in Cola and Pepsi P - value $\mathrm{p}<$ 0.034 and $\mathrm{p} 0.043$ respectively.

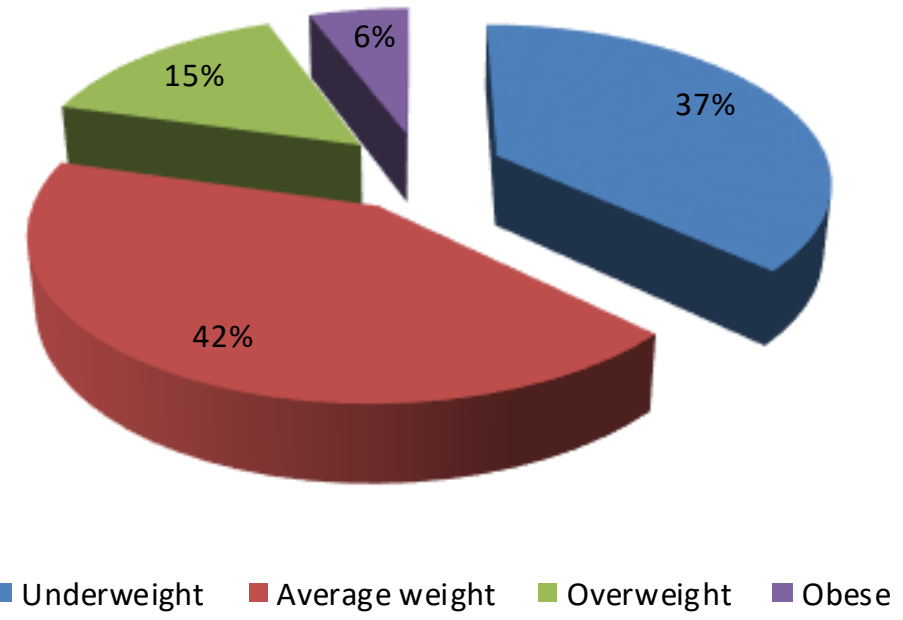

\section{BMI of studied school children}

Figure (1): Distribution of the studied school children according their level of BMI 
Table (1): Relationship between characteristics of the studied school children and their BMI $(\mathrm{N}=697)$

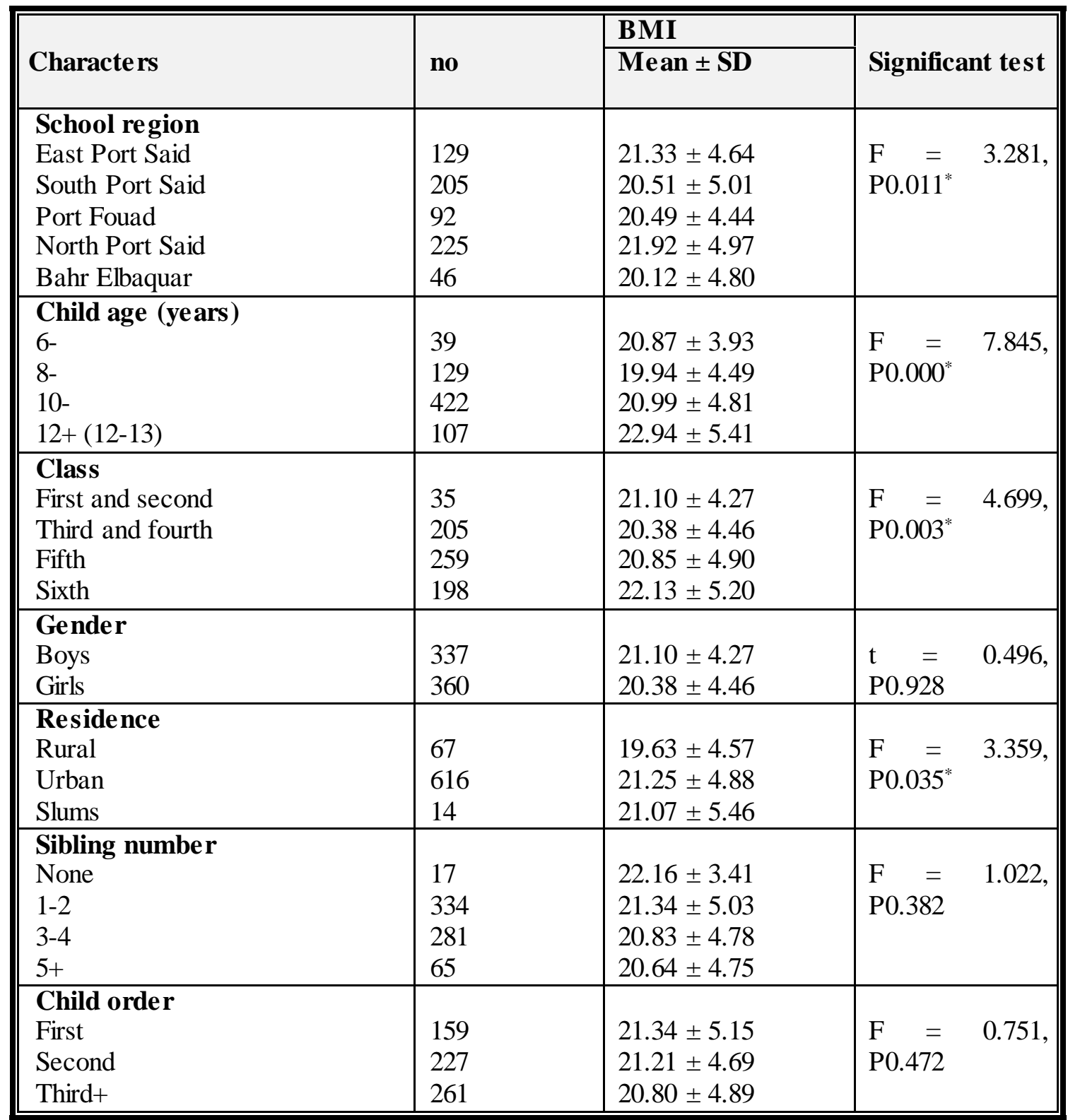

* statistically significant at $\mathrm{P}$ - value $\leq 0.05$

$\mathrm{P}: \mathrm{F}$ and $\mathrm{P}$ values for a nova test, $\mathrm{P}$ :t Student (T test) 
Table (2): Comparison between school children with normal weight and (overweight and obese group) as regard their behaviors $(\mathrm{N}=439)$.

\begin{tabular}{|c|c|c|c|c|c|}
\hline \multirow[t]{2}{*}{ Behaviors } & \multicolumn{2}{|c|}{$\begin{array}{c}\text { Normal weight } \\
(295)\end{array}$} & \multicolumn{2}{|c|}{$\begin{array}{c}\text { Overweight and } \\
\text { obese (144) }\end{array}$} & \multirow[t]{2}{*}{$\begin{array}{c}\text { Significant } \\
\text { test }\end{array}$} \\
\hline & no & $\%$ & no & $\%$ & \\
\hline $\begin{array}{l}\text { Child sit on front of } \\
\text { Television /computer } \\
\text { No } \\
\text { Yes }\end{array}$ & $\begin{array}{l}41 \\
254\end{array}$ & $\begin{array}{l}13.9 \\
86.1\end{array}$ & $\begin{array}{l}10 \\
134\end{array}$ & $\begin{array}{l}6.9 \\
93.1\end{array}$ & $\begin{array}{l}\chi^{2}=5.610, \\
\text { P0.033* }\end{array}$ \\
\hline $\begin{array}{l}\text { Number of hours Child } \\
\text { sit on front of Television } \\
\text { /computer } \\
<1 \text { hour } \\
2-3 \text { hours } \\
4+\text { hours }\end{array}$ & $\begin{array}{l}66 \\
154 \\
34\end{array}$ & $\begin{array}{l}26 \\
60.6 \\
13.3\end{array}$ & $\begin{array}{l}28 \\
75 \\
31\end{array}$ & $\begin{array}{l}21 \\
56 \\
23\end{array}$ & $\begin{array}{l}\chi^{2}=10.951, \\
\text { P0.019* }\end{array}$ \\
\hline $\begin{array}{l}\text { Sleeping hours per day } \\
6 \\
7 \\
8 \\
9+\end{array}$ & $\begin{array}{l}37 \\
52 \\
166 \\
40\end{array}$ & $\begin{array}{l}12.5 \\
17.6 \\
56.3 \\
13.6\end{array}$ & $\begin{array}{l}9 \\
19 \\
86 \\
30\end{array}$ & $\begin{array}{l}6.3 \\
13.2 \\
59.7 \\
20.8\end{array}$ & $\begin{array}{l}\chi^{2}=8.242, \\
\mathrm{P} 0.041^{*}\end{array}$ \\
\hline
\end{tabular}

$* p: \chi$ statistically significant at $\mathrm{P} \leq 0.05$ Chi square $\left(\chi^{2}\right)$ 
Table (3): Comparison between school children with normal weight and (overweight and obese group) as regard their Eating habit $(\mathrm{N}=439)$.

\begin{tabular}{|c|c|c|c|c|c|}
\hline \multirow[t]{2}{*}{ Eating habits } & \multicolumn{2}{|c|}{ Average (295) } & \multicolumn{2}{|c|}{$\begin{array}{c}\text { Overweight } \\
\text { and obese } \\
(144)\end{array}$} & \multirow[t]{2}{*}{$\begin{array}{c}\text { Significant } \\
\text { test }\end{array}$} \\
\hline & no & $\%$ & no & $\%$ & \\
\hline $\begin{array}{l}\text { Number of eating per day } \\
\text { One } \\
\text { Two } \\
\text { Three } \\
\text { Four and more }\end{array}$ & $\begin{array}{l}13 \\
80 \\
192 \\
10\end{array}$ & $\begin{array}{l}4.4 \\
27.1 \\
65.1 \\
3.4\end{array}$ & $\begin{array}{l}4 \\
27 \\
100 \\
13\end{array}$ & $\begin{array}{l}2.8 \\
18.8 \\
69.4 \\
9.0\end{array}$ & $\begin{array}{l}\chi^{2}=9.590 \\
\mathrm{P} 0.022^{*}\end{array}$ \\
\hline $\begin{array}{l}\text { Eating during Television watch or } \\
\text { computer use } \\
\text { No } \\
\text { Yes }\end{array}$ & $\begin{array}{l}97 \\
198 \\
\end{array}$ & $\begin{array}{l}32.9 \\
67.1 \\
\end{array}$ & $\begin{array}{l}33 \\
111 \\
\end{array}$ & $\begin{array}{l}22.9 \\
77.1\end{array}$ & $\begin{array}{l}\chi^{2}=4.611, \\
P 0.032^{*}\end{array}$ \\
\hline $\begin{array}{l}\text { Number of meals } \\
\text { No } \\
\text { One } \\
\text { Two } \\
\text { Three }+ \\
\end{array}$ & $\begin{array}{l}97 \\
113 \\
66 \\
19 \\
\end{array}$ & $\begin{array}{l}32.9 \\
38.3 \\
22.4 \\
6.4\end{array}$ & $\begin{array}{l}33 \\
41 \\
40 \\
30\end{array}$ & $\begin{array}{l}22.9 \\
28.5 \\
27.8 \\
20.8 \\
\end{array}$ & $\begin{array}{l}\chi^{2}=25.040 \\
\mathrm{P} 0.000^{*}\end{array}$ \\
\hline $\begin{array}{l}\text { Eating bre akfast } \\
\text { No } \\
\text { Yes } \\
\end{array}$ & $\begin{array}{l}91 \\
204\end{array}$ & $\begin{array}{l}30.8 \\
69.2 \\
\end{array}$ & $\begin{array}{l}59 \\
85 \\
\end{array}$ & $\begin{array}{l}41.0 \\
59.0\end{array}$ & $\begin{array}{l}\chi^{2}=4.410, \\
P 0.036^{*}\end{array}$ \\
\hline $\begin{array}{l}\text { Eating before going to bed } \\
\text { No } \\
\text { Yes }\end{array}$ & $\begin{array}{l}177 \\
118\end{array}$ & $\begin{array}{l}60.0 \\
40.0\end{array}$ & $\begin{array}{l}71 \\
73\end{array}$ & $\begin{array}{l}49.3 \\
50.7\end{array}$ & $\begin{array}{l}\chi^{2}=4.502, \\
\text { P0.034 }\end{array}$ \\
\hline $\begin{array}{l}\text { Eating fast food } \\
\text { No } \\
\text { Yes }\end{array}$ & $\begin{array}{l}227 \\
68 \\
\end{array}$ & $\begin{array}{l}76.9 \\
24.1 \\
\end{array}$ & $\begin{array}{l}96 \\
48 \\
\end{array}$ & $\begin{array}{l}66.7 \\
33.3 \\
\end{array}$ & $\begin{array}{l}\chi^{2}=5.262, \\
\mathrm{P} 0.021^{*}\end{array}$ \\
\hline $\begin{array}{l}\text { Number of eating sweets } \\
\text { No } \\
\text { Once/day } \\
\text { Twice/day } \\
\text { > Twice/day } \\
\text { One/week } \\
\text { Twice/week } \\
\text { >twice/week }\end{array}$ & $\begin{array}{l}26 \\
134 \\
43 \\
43 \\
26 \\
12 \\
11\end{array}$ & $\begin{array}{l}8.8 \\
45.4 \\
14.6 \\
14.6 \\
8.8 \\
4.1 \\
3.7\end{array}$ & $\begin{array}{l}10 \\
43 \\
28 \\
32 \\
12 \\
10 \\
9\end{array}$ & $\begin{array}{l}6.9 \\
29.9 \\
19.4 \\
22.2 \\
8.3 \\
6.9 \\
6.3\end{array}$ & $\begin{array}{l}\chi^{2}=13.930, \\
\text { P0.030* }\end{array}$ \\
\hline $\begin{array}{l}\text { Type of favorite food to your child } \\
\text { No } \\
\text { Food contain protein } \\
\text { Food contain CHO } \\
\text { Vegetables } \\
\text { Fruits } \\
\text { Mixed }\end{array}$ & $\begin{array}{l}11 \\
72 \\
58 \\
35 \\
70 \\
49\end{array}$ & $\begin{array}{l}3.7 \\
24.4 \\
19.7 \\
11.9 \\
23.7 \\
16.6\end{array}$ & $\begin{array}{l}6 \\
28 \\
39 \\
9 \\
26 \\
36\end{array}$ & $\begin{array}{l}4.2 \\
19.4 \\
27.1 \\
6.3 \\
18.1 \\
25.0\end{array}$ & $\begin{array}{l}\chi^{2}=11.490, \\
\text { P0.042 }\end{array}$ \\
\hline $\begin{array}{l}\text { Eating vegetables regularly } \\
\text { No } \\
\text { Yes }\end{array}$ & $\begin{array}{l}166 \\
129\end{array}$ & $\begin{array}{l}56.3 \\
43.7\end{array}$ & $\begin{array}{l}99 \\
45\end{array}$ & $\begin{array}{l}68.8 \\
31.2\end{array}$ & $\begin{array}{l}\chi^{2}=6.301, \\
\mathrm{P} 0.012^{*}\end{array}$ \\
\hline $\begin{array}{l}\text { Eating food at school } \\
\text { No } \\
\text { Home made } \\
\text { Fast food } \\
\text { Sweets } \\
\text { Mixed }\end{array}$ & $\begin{array}{l}10 \\
194 \\
6 \\
77 \\
8\end{array}$ & $\begin{array}{l}3.4 \\
65.8 \\
2.0 \\
26.1 \\
2.7\end{array}$ & $\begin{array}{l}5 \\
80 \\
11 \\
44 \\
4\end{array}$ & $\begin{array}{l}3.5 \\
55.5 \\
7.6 \\
30.6 \\
2.8\end{array}$ & $\begin{array}{l}\chi^{2}=11.172, \\
\mathrm{P} 0.037^{*}\end{array}$ \\
\hline
\end{tabular}


Table (4): Comparison between school children with normal weight and (overweight and obese group)as regard their Eating outside home and taking snacks $(\mathrm{N}=439)$.

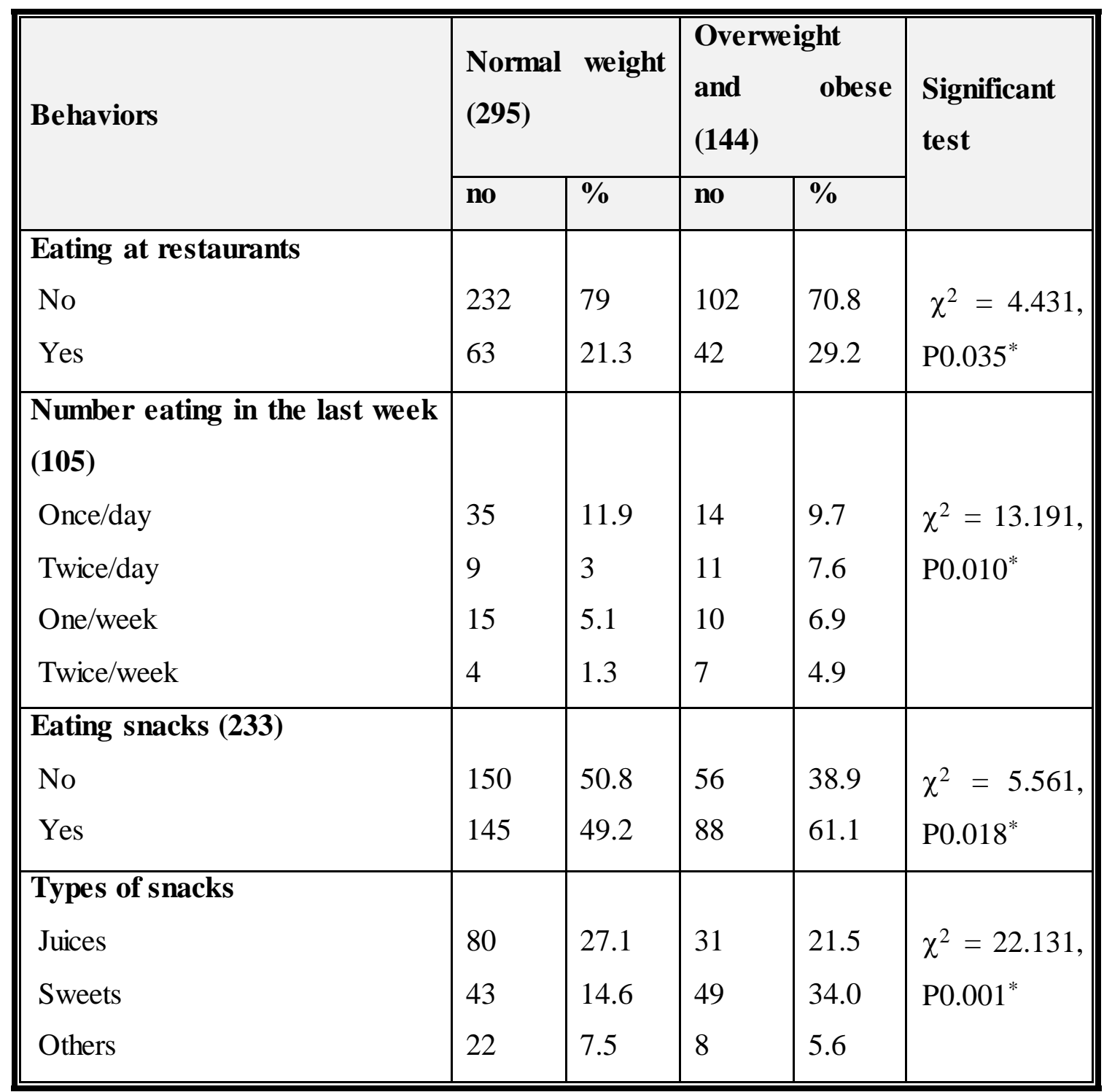

$* p: \chi$ statistically significant at $\mathrm{P} \leq 0.05$ Chi square $\left(\chi^{2}\right)$ 
Table (5): Comparison between school children with normal weight and (overweight and obese group) as regard their eating salted food and types of juices $(\mathrm{N}=439)$

\begin{tabular}{|c|c|c|c|c|c|}
\hline \multirow[t]{2}{*}{ Behaviors } & \multicolumn{2}{|c|}{$\begin{array}{l}\text { Normal } \\
\text { weight(295) }\end{array}$} & \multicolumn{2}{|c|}{$\begin{array}{l}\text { Overweight } \\
\text { and obese (144) }\end{array}$} & \multirow[t]{2}{*}{$\begin{array}{l}\text { Significant } \\
\text { test }\end{array}$} \\
\hline & no & $\%$ & no & $\%$ & \\
\hline \multicolumn{6}{|c|}{ child eating salted food } \\
\hline No & $\begin{array}{l}75 \\
220\end{array}$ & $\begin{array}{l}25.4 \\
74.6\end{array}$ & $\begin{array}{l}25 \\
119\end{array}$ & $\begin{array}{l}17.4 \\
82.6\end{array}$ & $\begin{array}{l}\chi^{2}=4.111, \\
P 0.043^{*}\end{array}$ \\
\hline \multicolumn{6}{|c|}{ types of juices child drink } \\
\hline$-\mathrm{No}$ & 9 & 3.1 & 6 & 4.2 & \\
\hline -Cola and Pepsi & 109 & 36.9 & 60 & 41.7 & $\chi^{2}=12.441$, \\
\hline -Fruit juice & 138 & 46.8 & 40 & 27.8 & \\
\hline -Chocolates & 10 & 3.4 & 7 & 4.9 & \\
\hline -More the one type & 29 & 9.8 & 22 & 15.3 & \\
\hline
\end{tabular}

$* p: \chi$ statistically significant at $\mathrm{P} \leq 0.05$ Chi square $\left(\chi^{2}\right)$

\section{DISCUSSION:}

Obesity is becoming one of the most important concerns that affect the wellbeing of populations. It is a major public health problem resulting in serious social, physical and psychological damage. By the end of the 20th century, the WHO has considered obesity as a 'global epidemic' that has involved all age groups. It is responsible for more than two million deaths each year regardless of economic status of the countries (Taheri et al., 2015).

The result study revealed that prevalence of overweight and obesity was high among primary schools children in Port Said city nearly quarter among studied 
children, Egypt. This results agreement with (Saleh et al 2017). Similar previous finding BMI of primary school children in Dire Dawa City, Eastern Ethiopia obesity and overweight nearly quarter among studied children. More recently, rates have been reported from other Arab countries. According to a recent national study in Saudi Arabia 29.6\% and aged 6-12 are overweight, obese. Recently, similar rates were reported from other by the previous Egyptian study conducted by Shafei and others who showed the prevalence of overweight and obesity of 11.5 and $8.8 \%$, respectively, between children in Al-Bagour neighborhood. In addition Shafei et al (2014) found that proliferation weight gain and obesity in the neighborhood of Sinbillawin was 11.5 and $8.5 \%$, respectively. This result may be due to of obesity child sit on front of television / computers or eating during television watch or computer use.

Regarding characteristics of the studied school children the present study revealed that the prevalence of overweight and obesity increased at the age of 10-12 years. This finding nearly two third of study sample. This results agreement with (Saleh et al 2017) Similar previous finding BMI of primary school children in Dire Dawa City, Eastern Ethiopia. A study carried out by(Shakoorand Al-deen,2015) who found that the prevalence of overweight and obesity increased at the age of 8-10 years. Also, a study carried out in Egypt by (Badawi et al. 2013) who estimated the prevalence of overweight and obesity among primary school children, aged from 6 to 12 years and to estimate risk factors of obesity and overweight and found that The rate of obesity was the highest at the age of $7-8$ years. This finding may be due to attribute to less physical activity and more access to unhealthy foods among school children.

The present study finding the prevalence of overweight and obesity higher percentage at the obesity in urban areas than rural areas. This is in agreement with most previous studies conducted in Egypt (Bertoncello C, Cazzaro R, Ferraresso A, Mazzer R, Moretti G,2007 and El- Shafei et al., 2014) found that the prevalence of overweight and obesity was increased urban versus rural children. This might be due to availability of fast food restaurants.

The findings of this study revealed that the prevalence of overweight and obesity among studied children watching TV and eat in watching TV. This result was agreement with a study by (Padilla et al. 2012) studies conducted in Narbonne found that watching TV more than two hours/ day lead to childhood obesity, and that eating in front of TV is one of the causes of obesity and other study Similarity in Bahir Dar 
city by( Mekonnen et al. 2018) found that watching TV more than two hours/ day lead to children obesity This may be due to consumption of high caloric food, in addition to longer duration of $\mathrm{TV}$ watching might lead to more frequency of consumption of fast foods.

Regarding their behaviors this study findings significant differences between studied children Sleeping hours per day groups beside higher in sleeping 8 hours per day findings significant differences between average BMI in different. This is in disgreement by (Morrissey B, Malakellis M, Whelan J, MillarL, Swinburn B, Allender S and Strugne C, 2016) a study in Victorian city Lack of sleep below $8 \mathrm{~h}$ may cause obesity through increased sympathetic activity This may be due to decreased of physical activity.

The result of the current study as regards eat habits this study findings significant differences between studied children that the number of meals eaten per day association between the prevalence of overweight and obesity. This is in disagreement by (Saleh et al., 2017) studies conducted in Riyadh and Al-Ahsa regions, in Saudi Arabia there was no significant association between the prevalence of overweight/obesity and the number of meals eaten per day. This may be due to the length of time in schools and not to give three meals regularly and thus to be obese.

Regarding to the children's eat habits, the present study showed that over two quarter of the obese and overweight children take their breakfast. This is was agreement studies by(Saleh et al, 2017) conducted in Riyadh and Al-Ahsa regions, in Saudi Arabia found statistical relation between eating breakfast and occurrence of obesity.in same time thus disagreement conducted in "Algeria, Morocco, Tunisia by(Abdelkafi et al., 2012) found no statistical relation between eating breakfast and occurrence of obesity. This may be due to poor's mother's knowledge about important of breakfast.

Regarding their eat habits this study findings significant differences between studied children eating before going to bed. This is was agreement with a study by (Ohidullah et al 2014) conducted in Bangladesh found statistical relation between eating before going to bed and overweight and obesity. This may be due to leak of knowledge about should be taking rest after lunch was found to have appositive association with BMI. 
Regarding their eat habits this study findings significant differences between studied children to type of favorite. This is was agreement by (Said, 2013) He studies conducted in Mansoura city found that increase intake of high energy food as carbohydrate which increase the prevalence of obesity and overweight, a study conducted in Bahir Dar City found indicated that low fruit and vegetable intake was associated with higher risk of being overweight/ obese low fruit and vegetable intake was associated with higher risk of being overweight and obese. This may be due to loss knowledge of the mother about the required quantity of food quantity.

Regarding their eat habits this study findings significant differences between the overweight/obesity and eating food at school and type of snake, sweet slightly. This was agreement with a study by (Mohamed 2007and Said 2013) He studies conducted in Mansoura city children took sweets as snack high in calories easily increase the weight. a study conducted in Egypt by (Salem et al, 2016) who estimated the prevalence and identify possible risk factors for obesity in a representative sample of primary school children (6-12 years) in Menoufia Governorate and found that there was significantly higher among those take high calorie snacks like sweets or chips than in those who take low caloric snacks like vegetables and fruits. a study conducted in Ethiopia by (Gebrie A, Alebel A, Zegeye A, Tesfaye B and Ferede A, 2018) who determine the pooled prevalence and review associated risk factors of overweight/obesity among children and adolescents in Ethiopia and found that there was significantly higher among those take high calorie snacks like sweets and obesity and overweight. This may be due to theses food had a lot of sugar that lead to obesity.

The findings of this study revealed that the prevalence of overweight and obesity was nearly more quarter among studied children eating outside home and taking snacks the present study finding demonstrated that, there was significant association between the prevalence of overweight/obesity and Eating at restaurants. This result was in agreement with a study by (Sahoo et el, 2015) He a study conducted in Durban Foods served at fast food restaurants tend to contain a high number of calories with low nutritional values. Caloric intake before or after the fast food meal in anticipation or compensation for the excess calories consumed during the fast food meal a causal relationship between fast food and obesity. This may be due to the sample is more in the city than the countryside and therefore there are more restaurants. 
The findings of this study revealed that the eating salted food and types of juices especially Cola and Pepsi prevalence of overweight and obesity was over three quarter among studied children eating salted food. This result was in agreement with a study by (Datar and Rand 2012). He conducted in United State foods and beverages available or sold in schools outside of the school lunch and breakfast programs the foods available in the schools chips, soft drinks. Children who drink soft drinks four or more days per week. .In same time thus disagreement conducted in Egypt by (Mostafa 2006) with this study and found there was no significant differences between the prevalence of overweight/obesity and drinking fruit juice. This may be due to theses juice had increase the incidence of obesity and overweight. Cola and Pepsi are available in many cafeterias in schools.

\section{CONCLUSION:}

This are a high significant relation between normal weight and over weight and obesity with eating habit and also eating out side the home and taking snakes.

\section{RECOMMENDATIONS:}

Based on the findings of the present study, the following recommendations are suggested:

- Assessment of parent knowledge should be a routinely as a part of the management process because parent is the first and important care givers for these children.

- Improve knowledge of parent about modification of behaviors life styles through visual aids such as posters, illustrated pamphlets in simple and clear language booklets.

- Establishing documents about basic data about obesity children in Port Said city.

- Educational efforts and reinforcement must be continuous to meet the needs of the parent and their children among primary schools. 


\section{REFERENCES:}

Abd El-matty G.M. (2009). Effect of weight loss program on self-esteem,body image of obese Egyptian women. J Az Med Fac (GIRLS), 16 (1) P: 43.

Abdelkafi, A. K., Younes, K., Gabsi, Z., Bouslah, A., Maalel, I., Maatouk, W. E. M., ... \& Tekaya, M. S. (2012). Risk factors of children overweight and obesity. La Tunisie medicale, 90(5), 387-393.

Ameen, S. A., \& Abdelazeim, F. H. (2015). Effect of Obesity on Cognitive Performance in Egyptian School-Age Children. Trends in Applied Sciences Research, 10(3), 166 .

Ankara, Turkey (2010). Ministry Of Health Of Turkey General Directorate Of Primary Health Care, Obesity Prevention And Control Program Of Turkey, Ankara, Turkey, N500 P P:18

Badawi, N. E. S., Barakat, A. A., El Sherbini, S. A., \& Fawzy, H. M. (2013). Prevalence of overweight and obesity in primary school children in Port Said city. Egyptian Pediatric Association Gazette, 61(1), 31-36.

Bertoncello, C., Cazzaro, R., Ferraresso, A., Mazzer, R., \& Moretti, G. (2008). Prevalence of overweight and obesity among school-aged children in urban, rural and mountain areas of the Veneto Region, Italy. Public health nutrition, 11(9), 887-890.

Center for control disease (2009). Body Mass Index: Considerations for Practitioners. Retrieved from http://www.cdc.gov/healthyweight/assessing/bmi/childrens_bmi/tool_for_schools.htm $\underline{1 .}$

Datar, A., \& Nicosia, N. (2012). Junk food in schools and childhood obesity. Journal of Policy Analysis and Management, 31(2), 312-337.

El-Gilany, A. H., Abdel-Hady, D., \& Sarraf, B. (2014). Dietary habits of adolescent students in Mansoura, Egypt. International Journal of Collaborative Research on Internal Medicine \& Public Health, 6(6), 132. 
El-Shafie, A. M., Hogran, H. H., \& Dohein, A. M. (2014). Prevalence of obesity in primary school children living in Alexandria governorate. Menoufia Medical Journal, 27(3), 529.

Gebrie, A., Alebel, A., Zegeye, A., Tesfaye, B., \& Ferede, A. (2018). Prevalence and associated factors of overweight/obesity among children and adolescents in Ethiopia: a systematic review and meta-analysis. BMC obesity, 5(1), 19.

James M \& Rippe , MD (2012) .obesity : prevention and treatment, $1^{\text {st }}$ ed., united states of Americal ,Taylor ,Francis group P: 8

Kuhle, S., Doucette, R., Piccinini-Vallis, H., \& Kirk, S. F. (2015). Successful childhood obesity management in primary care in Canada: what are the odds?. PeerJ, 3, (1327), 1-2.

Mekonnen, T., Tariku, A., \& Abebe, S. M. (2018). Overweight/obesity among school aged children in Bahir Dar City: cross sectional study. Italian journal of pediatrics, 44(1), 17.

Mohammed, M. (2007). Epidemiological study of obesity among medical students in Mansoura University. Master Thesis, Faculty of Medicine, Mansoura University.

Morrissey, B., Malakellis, M., Whelan, J., Millar, L., Swinburn, B., Allender, S., \& Strugnell, C. (2016). Sleep duration and risk of obesity among a sample of Victorian school children. BMC public health, 16(1), 245.

Mostafa, s (2006). Relationship Between Obesity and Hypertension among Elementary School. Unpublished Master Theses.

National Association of School Nurses.(2013). The role of School Nursing. Silver Spring, MD: National Association of School Nurses; 2013.retrived from www.nasn.org/Default.aspx?tabid=57

Norman J,Trmple and ted Wilson,Geroge A,Bray( 2017).Nutrition Guide for physicians and related health care professionals, young children preparing for the futures, $2^{\text {nd }} .$, Canada, $174-199$. 
Ohid Ullah MD. Abu Hasan, MM, Chowdhur y A, Das NC, Uddin MJ, Uddin MT (2014). Obesity of Primary School Children: A Cross-sectional Study in Bangladesh. International Journal of Scientific and Engineering Research , 5(12) ,263-267.

Padilla, N., Biason, M. L., \& Ledésert, B. (2012). Prevalence and Risk Factors of Being Overweight among 5-to 11-Year-Old Schoolchildren in Narbonne (France). Sante publique, 24(4), 317-328.

Pangani, I. N., Kiplamai, F. K., Kamau, J. W., \& Onywera, V. O. (2016). Prevalence of overweight and obesity among primary school children aged 8-13 years in Dar es Salaam city, Tanzania. Advances in preventive medicine, 2016.

\section{السمنة بين اطفال المدارس الابتدائية فى محافظة بورسعيد: حجم الانتشار والعوامل المرتبطة بها أ.د/جهاد محمد ابو المعاطي , أ.د/محمد محمد المزاحي, أ. م.د/ نجلاء إبراهيم محمد، سلوى صالح عبدالفتاح عبدالجليل

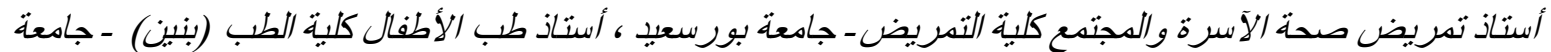

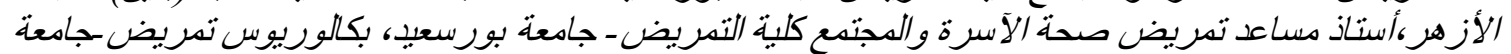 المنوفيه (2004)}

\section{الخلاصة}

مقدمة: نتزايد مخلات انتسر السمنة بين أطفل المدارس الابتدائية بصورة مضطردة ومثيرة لللق في جميع أنحاء لعالم. ومع ارتفاع تلك المعدلات بين الأطفال في لدول المتقمة بصفة خلهة إلا نٔ انتشار لسمنة يتزايد أيضاً في لدول النامية: الههف من الدراسة: نم إجراء الدراسة الحلية بهرف تقيم لسمنة بين الأطفال في لمدارس الابكائية من خلال الاتثار والعواهل المرنبطة بها. وقد نم إجراء الدراسة كرلسة وصفية مقطعية. مكان الاراسة: أجريت هذه الررلة في خمس مدارس ابكائية حكمية بمنطقة مدينة بورسعيد. العينة: نم لختيار عينة عثوائية من أطفال

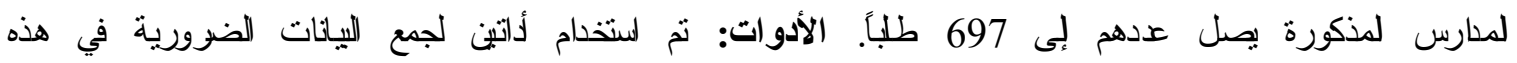
للراسة: الأكاة الأولى وهى عبارة ورقة لستبيان المقابلة لجمع الييانات عن لاعوامل لليموجرافية والاجتماعية وأنماط

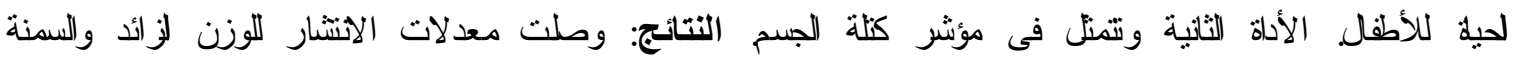
بصفة علمة إلى 20,6٪. وكنفت للراسة أن المؤشرات الأكزر لستقالاية للتنؤ بزياة الوزن والسمنة هي وهود نل كبِ بنسبة 45.3\% وأكزَ من ثلاثة أرباع الأطفال الشاركين فى الدرلسة كلوا يتناولون الطعلم أثناء مشلهاتة

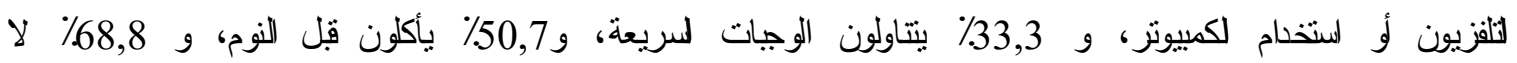
يأكلون الخضار بلتظام، بالإضفة إلى ذك، قد كلت نبة 41\% من الأطفل لا ينتاولون وجبة الإفطار. الخلاصة: توصلت الدراسة إلى وجود علاقة ذات دلالة إحصائية عالية بين الوزن الطييعي والوزن الزئد والسمنة مع عادات 